\title{
Reducing carbon emissions: Strathmore University contributions towards sustainable development in Kenya
}

\author{
Author: \\ Ms Lilian Njeri Munene ${ }^{1}$ \\ Affiliation: \\ ${ }^{1}$ United States \\ International University - \\ Africa, Kenya \\ E-mail: \\ lilian.njeri@ayenitalolom. \\ africa \\ DOI: \\ 10.15249/13-1-173

\section{Keywords:} \\ carbon emissions; higher \\ education; inclusive \\ development; solar \\ PV power; sustainability
}

\section{Abstract}

Strathmore University is the first educational institution in sub-Saharan Africa to achieve a zero-carbon footprint. With 2400 panels located on the roofs of six buildings, it is the largest rooftop solar installation in the region. Kenya sits on the equator and enjoys year-round insolation. Taking advantage of a green line of financial support created by the French Government, Strathmore embarked on a project to install a $600 \mathrm{~kW}$ rooftop, grid-connected solar photovoltaic (PV) power system to cater for its electricity needs. The system is designed to produce more than the required self-consumption hence the extra power is sold to the utility via a power purchase agreement. This investment in renewable energy confirms that universities can demonstrate leadership in the area of environment and energy. This article describes the economic and social impact created by a university through greening its sources of energy.

\section{Introduction}

Limited energy access and climate change are the main energy challenges that affect sub-Saharan Africa (SSA) (Avila et al., 2017). SSA has low electricity access of about $20 \%$, with the majority of the people being connected to an unreliable grid (Bazilian et al., 2012). According to the International Energy Agency (IEA), demand for electricity in SSA between 2000 to 2012 grew by 4\%. According to the International Energy Agency (2014), the demand for electricity in Africa will grow by $4 \%$ until year 2040 . This region is burdened with population growth, which is unmatched to the current electrification process. Therefore, by 2040, about 500 million people risk not having access to electricity (International Energy Agency, 2016). 


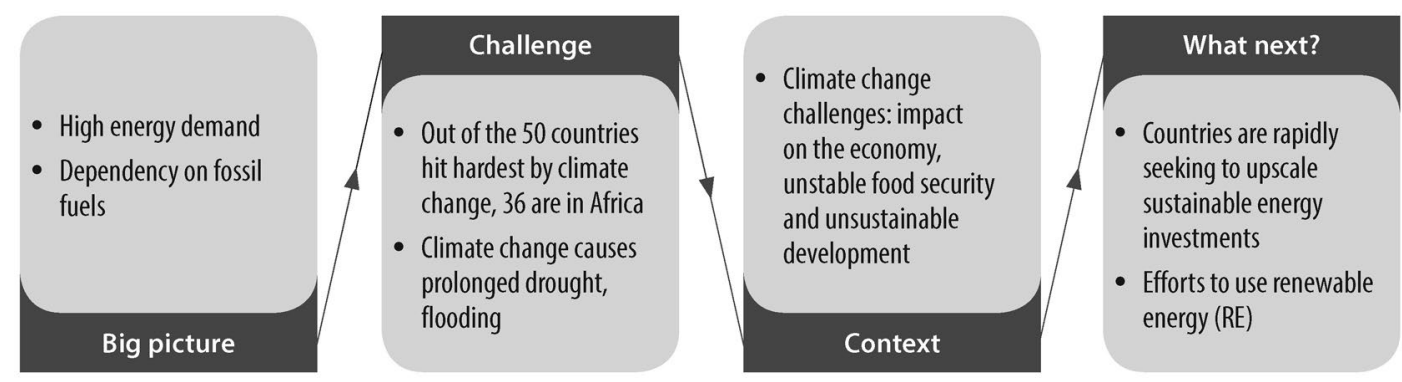

Figure 1: Demonstration of vulnerability caused by climate change in Africa

Avila et al. (2017) assert that global warming contributions from Africa are the least both in absolute and per capita terms. Only $3.8 \%$ of global greenhouse gases are emitted in Africa compared to China at 23\%, United States at $19 \%$ and the European Union at $13 \%$. Despite Africa's low carbon emissions, Adenle et al. (2017) note that it's the most vulnerable region to climate change. Climate change impacts the economy adversely by causing prolonged drought and floods leading to unstable food security and unsustainable development.

Deichmannet et al. (2011) assert that local renewable energy sources are more appealing since SSA nations have potential in renewable energy. It is therefore technologically feasible to exploit them using current technologies and because global trends are moving towards zero or low carbon renewable energy.

\section{Ethics of climate change}

Underlying the adverse impacts of climate change are ethical issues that people and governments should address. Climate ethicists interrogate the moral choices to guide on duties and responsibilities taken to reduce carbon emissions and effects of global warming (Gardiner, 2004). However, a moral dilemma arises as climate change adversely and disproportionately impacts poor and marginalised populations. While it is not clear who should bear the burden of responsibility of addressing climate change, these impacts cause conflicts between nations, regions and cities that are vulnerable to climate disruptions (Brown, 2013).

Climate ethicists propose mechanisms through which impacts of climate change can be addressed with fairness (Gardiner, 2004). Climate justice and equity concepts have driven mechanisms such as carbon tax aimed at pricing and reducing carbon emissions. Climate ethicists are vocal on the importance of people and governments taking up duties and responsibilities in order to protect our ecosystem (Broome, 2008); 195 countries have ratified the United Nations Framework Convention on Climate Change (UNFCCC). UNFCCC is an international agreement on climate change bringing counties together to respond appropriately to climate change impacts. The Paris Agreement came into force in 2016 with an action plan to limit global warming (Bodansky, 2016). 
In Kenya, climate change impacts are characterised by prolonged droughts, floods and unreliable weather patterns. These trends adversely affect Kenya's social-economic development (Oliver et al., 2017). The challenges affecting the nation's energy sector include a rise in demand for electricity that exceeds power supply capacity; overdependence on hydro-power leading to power rationing during adverse weather conditions such as drought, poor distribution network and power infrastructure, and low investments in power generation by the private sector (Maher et al., 2003).

East Africa's largest economy has committed under the Paris Agreement to tackle climate change by reducing carbon emissions by $30 \%$ by 2030 . This pledge is well anchored in the Kenya Climate Change Action Plan of 2013, which is a five-year plan building on the National Climate Change Response Strategy (NCCRS) of 2010. Kenya is a party to UNFCCC and classified as Non-Annex I for countries that have no legally binding GHG emissions reduction targets. However, Kenya has adopted mitigation strategies culminating in its ethical obligations towards tackling climate change and taking up its responsibilities to reduce carbon emissions (Oulu, 2014).

Kenya is on an ambitious economic journey to become an industrialised middle-income country by 2030. Growth of the energy sector will be required to match the needed levels of economic growth. To achieve both goals, the country recognises the need to acquire climate mitigation measures aimed at achieving the $30 \%$ emissions reduction target by expanding renewable energy sources (Oliver et al., 2017).

\section{Interventions by higher education institutions to reduce carbon emissions}

In 2016, $\mathrm{CO}_{2}$ emissions in SSA were recorded at 0.827 metric tons per capita (World Bank, 2016). Carbon emissions in SSA are growing rapidly due to combustion of fossil fuels, high population growth, increased deforestation and cattle production (Hogarth et al., 2015). According to Altan (2010), reducing current levels of carbon emissions by $25 \%$ will enable stabilisation of global $\mathrm{CO}_{2}$ concentrations to a level which will not have adverse impacts. To promote sustainability efforts, partnerships are being forged between the private sector, governments and Higher Education Institutions (HEIs) (Nhamo \& Ntombela, 2014). Universities today are viewed as agents of inclusive development. They are expected to lead in innovative strategies to reduce carbon emissions (Uhl \& Anderson, 2001).

HEls are playing a critical role by leading research, training and education as well as being solution providers to climate change challenges (Uhl \& Anderson, 2001). According to Nhamo and Ntombela (2014), universities have a moral responsibility to address climate change through teaching practice, developing new management strategies, research and their own practical actions. Institutions of higher learning are becoming the leading frontiers in fighting climate change. 
Kenya has intensified its efforts to reduce its carbon footprint. In 2010, the country launched the National Climate Change Response Strategy which was followed by the National Climate Change Action Plan in 2013. The action plan between 2013 and 2017 covers adaptation and mitigation efforts towards a low carbon climate resilient development country.

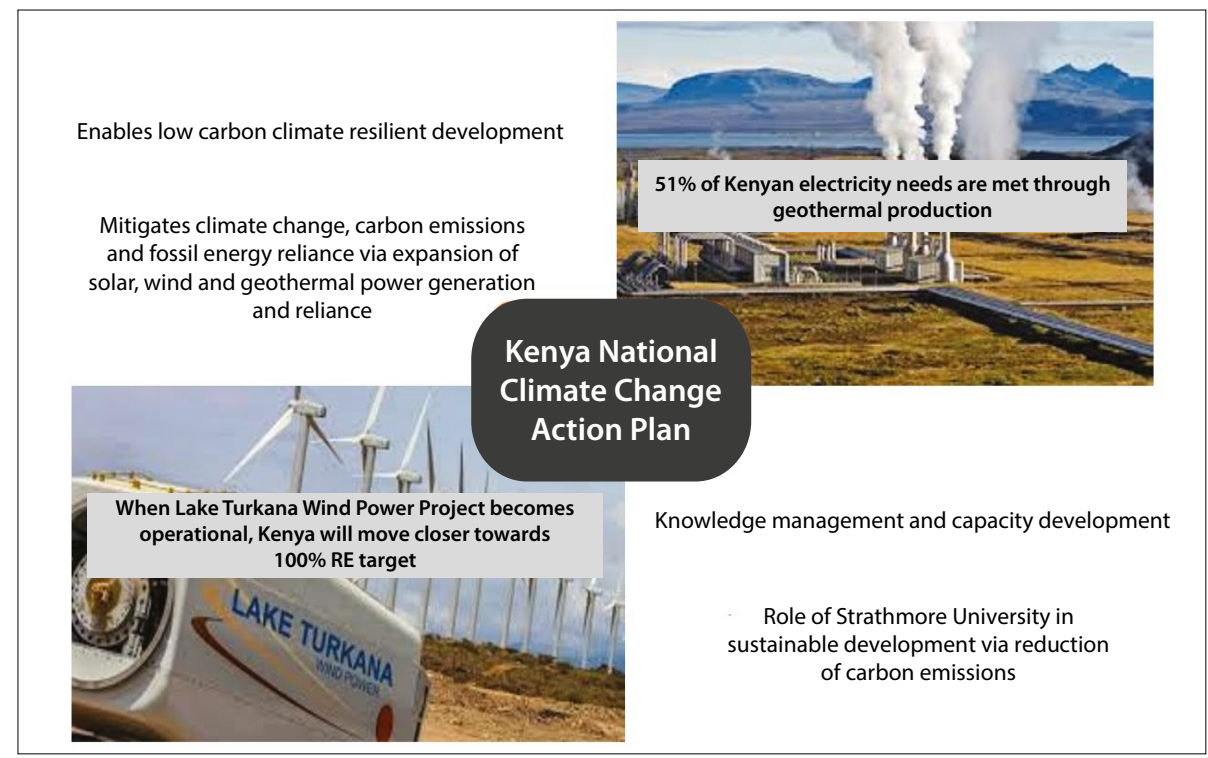

Figure 2: Summary of Kenya National Climate Change Action Plan 2013-2017

In the plan, HEls were empowered to integrate climate change into the education systems. Universities in Kenya have since then undertaken low carbon initiatives through teaching, research and innovation as well as developing climate change policies and strategies (Government of Kenya, 2013). In return, the Government of Kenya offers incentives to the Higher Education Institutions that invest in renewable energy by offering to buy power directly from these institutions.

\subsection{Strathmore University: Contributions towards sustainable development in Kenya}

Strathmore University (SU) is a Higher Education Institution based in Nairobi, Kenya. SU was initially founded as Strathmore College in 1961 and later awarded a charter in June 2007 to operate as fully-fledged university. To date, the University houses over 4000 students, 500 members of staff and close to a million visitors a year (Strathmore University, 2018).

Since its foundation Strathmore has always been an active contributor to inclusive development in Kenya and globally (Strathmore University Annual Report, 2015). In 1961, Strathmore became the first multi-racial institution in Kenya (Strathmore University, 2018). This was seen as an indignity by many - both the natives and the colonialists. However, it constitutes a leadership milestone underpinning future successes. 
Today, Strathmore University through Strathmore Energy Research Centre (SERC) actively explores and pursues opportunities that increase leadership and impact in clean energy and carbon emissions. Through teaching, research, policy development and actions both on and off campus, the University has aggressively addressed climate change challenges and consequently has become the region's reference point in sustainability efforts. The commitment has been further heightened by the development of the Centre for Sustainability Leadership that supports development of environmentally friendly and socially inclusive practices. Through SERC, the University has enacted management strategies addressing issues such as research on options to reduce carbon emissions, drawing carbon emissions, development and implementation of plans to reduce carbon emissions and training people in practices that promote renewable energy. The University has an approved sustainability policy through which a holistic vision and university-wide focus on sustainability is being achieved as internal and external stakeholders increase their awareness of renewable energy.

The University has been promoting sustainable construction and adapting buildings to climate change. New buildings including the Strathmore Business School (SBS), Management Science Building (MSB) and Student Centre (SC) have been constructed using the LEED (Leadership in Energy and Environmental Design) standards. These green buildings cover a space of $22000 \mathrm{~m}^{2}$ in total and they house offices, lecture halls, conference halls, recreational facilities and a cafeteria (Da Silva et al., 2015). Adapting buildings to climate change has led to a reduction of energy consumption by $40 \%$ (Da Silva \& Ssekulima, 2011).

\subsection{Strathmore University electricity consumption}

Electricity in the University is supplied by Kenya Power (KPLC) on Commercial Cl1 tariff at $415 \mathrm{~V}$ for two utility billing accounts. Electricity is consumed mostly for lighting, cooking, air ventilation, water heating, lifts, escalators, computers and other appliances. From January 2012, the demand and consumption for electricity in the University has been increasing. The trend is attributed to increased growth of the University, high number of added activities and increasing numbers of students and members of staff.

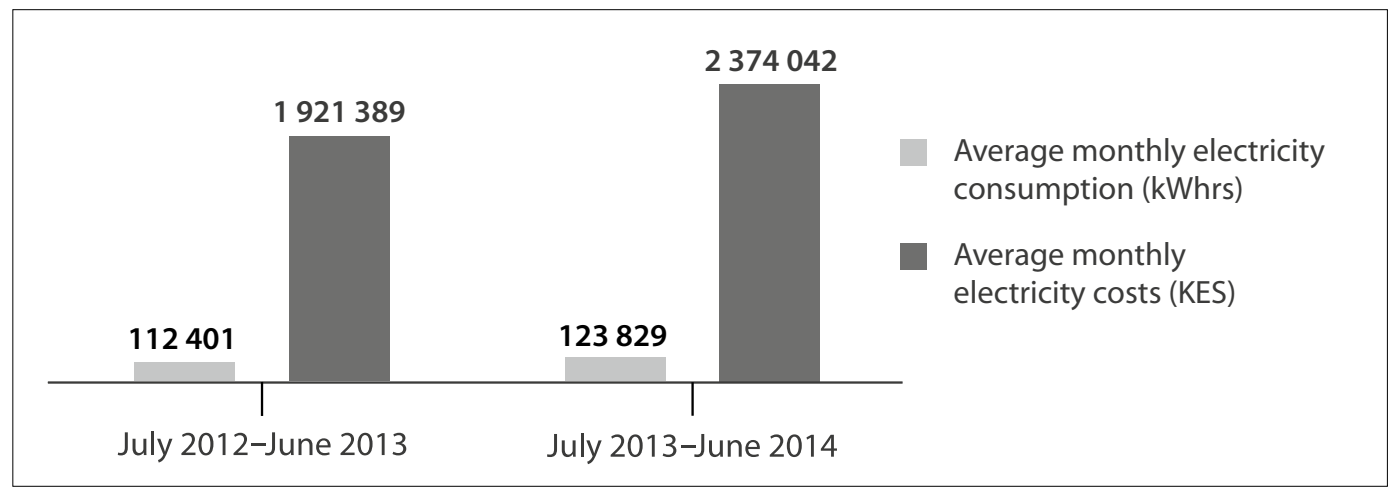

Figure 3: Electricity consumption at Strathmore University from July 2012 to June 2014 
As shown in Figure 3, the average consumption increased from 112,401 kWhrs in 2012/2013 to 123,829 in 2013/2014. Consequently, average electricity costs increased from KES $1,921,389$ in $2012 / 2013$ to KES 2,374,042 in $2013 / 2014$. The monthly average tariff increased from KES 17.09/kWhr to KES 19.17/kWhr in the same period.

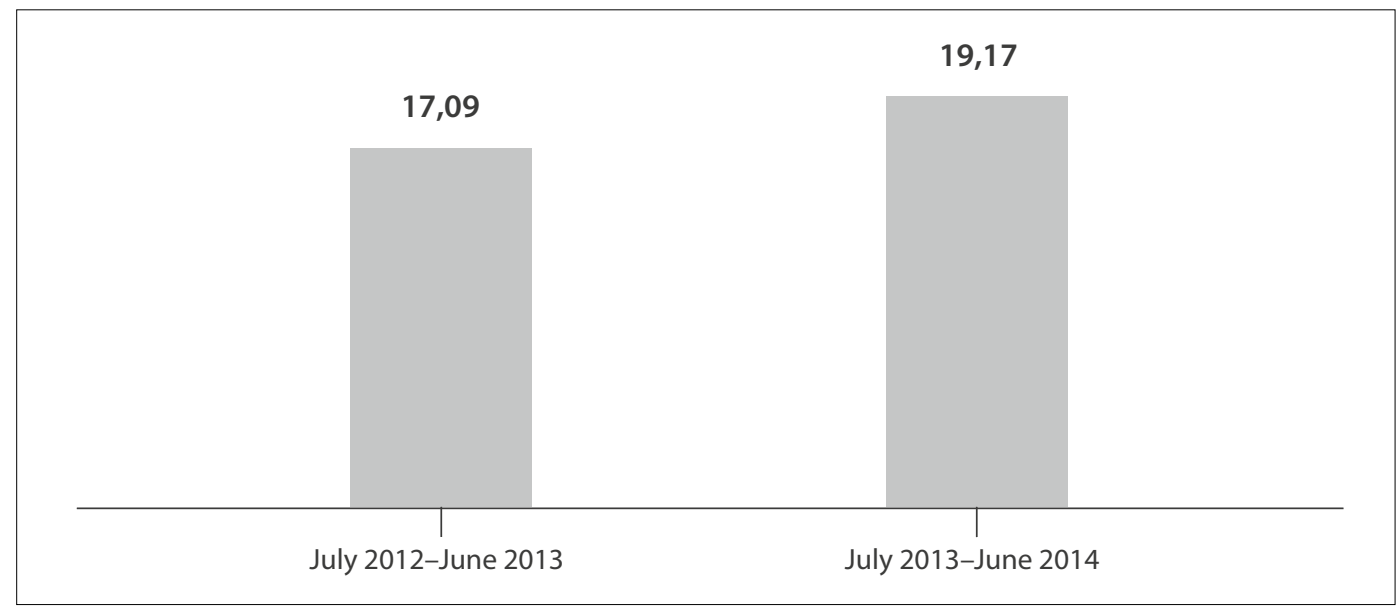

Figure 4: Average tariff charge (KES/kWhr) at Strathmore University from July 2012 to June 2014

Strathmore University installed a grid-connected rooftop solar photovoltaic (PV) system designed to supply the University's entire campus with electrical energy for a period of 25 years. The project was implemented with the aim of increasing sustainability efforts by partnering with global institutions to respond to climate change and carbon emissions.

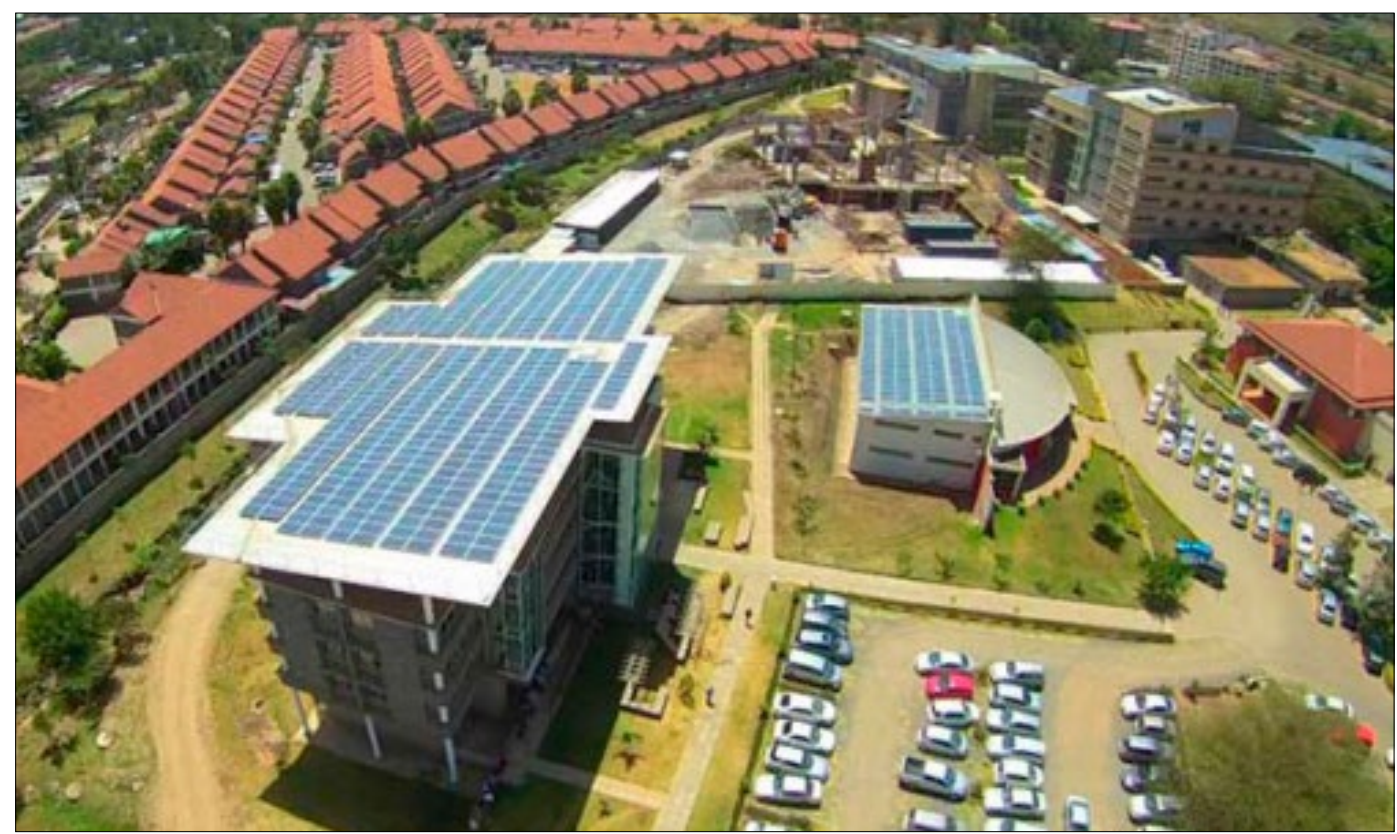

Figure 5: Strathmore University's green buildings with solar PV systems on the rooftop Source: SERC 
This article aims to present a case of inclusive development by a Kenyan university through investing in renewable energy. The implementation of the solar PV system in the University, energy production, consumption and dispatch to the national grid, financial impact and social/environmental impacts of the project confirm that HEls can demonstrate leadership in the area of environment and energy. The article also addresses the challenges encountered in the project.

\subsection{The Strathmore University solar PV project}

According to Shum and Watanabe (2009), solar PV has proved to be a mainstream technology for generating clean energy. solar PV has become a highly modular solution providing electricity solutions both on- and off-grid. Strathmore University embarked on an ambitious sustainability initiative to install a $600 \mathrm{~kW}$ rooftop grid-tied solar PV system which became fully operational on 24 June 2014. The solar PV systems are installed in six buildings around the University with production capacity distributed as $180 \mathrm{~kW}, 100 \mathrm{~kW}$, $80 \mathrm{~kW}, 80 \mathrm{~kW}$ and $40 \mathrm{~kW}$ as illustrated in Figure 6.

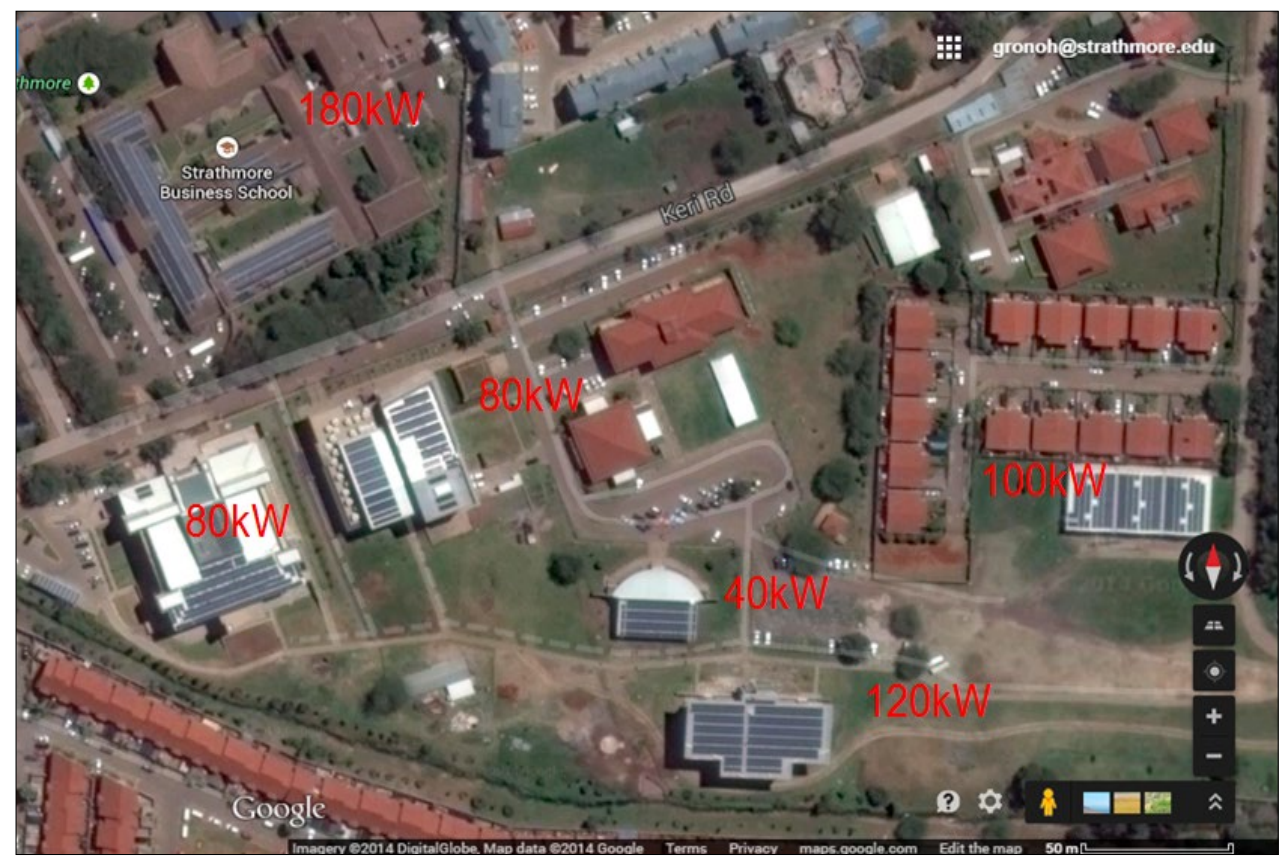

Figure 6: Installed rooftop grid-tied solar PV system in Strathmore University Source: SERC

The University invested in a solar PV power plant buoyed by the following factors:

- Awareness and knowledge of the University's senior management about solar PV technology, and its pioneering spirit.

- The University's location close to the equator giving it an advantage in tapping solar power due to the fact that it receives an average insolation of $4-6 \mathrm{kWh} / \mathrm{m} 2 /$ day without the need for sun tracking. 
- The existence of a green energy facility, set up by the French Development Agency, offering project financing at concessional rates.

- Additionally, the existing feed-in-tariff regime allowed the possibility of a gridconnected system without the need for storage which is always expensive and availing the possibility of selling to the utility excess power.

\subsection{Project financing and loan repayments}

The solar PV power plant was financed through a loan by Co-operative Bank of Kenya. The credit line was provided by Africa Development Bank Green Line of Credit at an interest rate of $4.1 \%$ over a 10 -year period, with one-year moratorium. However, through competitive sourcing of the solar PV system component parts, optimisation of the system size and the modular approach to the building of the system there were major cost discounts, which reduced the loan payback period from 10 to 7 years (Silva, 2013).

The energy produced by the solar PV system from June 2014 to June 2017 is 2,330,160.78 $\mathrm{kWhr}$. The average tariff for the period under review is KES $19 / \mathrm{kWhr}$, therefore, the production is equivalent to KES 44,273,055 (\$442,730.55). Average monthly production for the period under review is $64,726.69 \mathrm{kWhr}$ (equivalent to KES 1,229,807.08 per month). Based on the SERC measurements, $70 \%$ of the energy produced is consumed within the University and $30 \%$ is exported to the national grid metered at $11 \mathrm{kV}$ on a tariff of $\$ 0.12 / \mathrm{kWhr}$. Therefore, for the period under review, $699,048.23 \mathrm{kWhrs}$ were discharged to the grid.

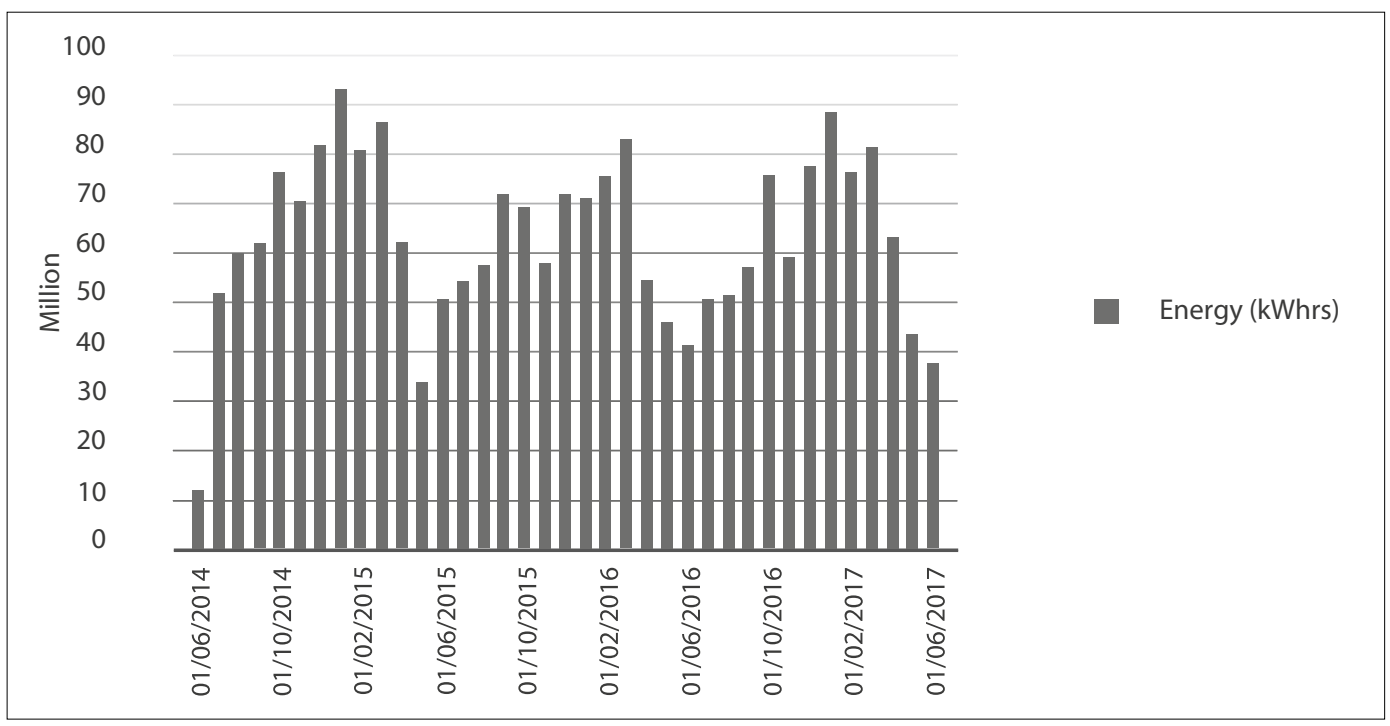

Figure 7: Monthly solar PV production (kWhrs) from June 2014 to June 2017 Source: SERC

Energy discharge to the national grid only happens during periods of low demand such as weekends or on holidays. This new trend has graduated Strathmore University to be a net importer of energy. 
Table 1 gives further details of the total earnings from the solar PV system for the period from June 2014 to June 2017. On average, the solar PV system earns the University KES 1,131,163.38 per month. This amount is sufficient to cover monthly loan repayments of KES 1,083,330 for 7 years. The solar PV system has a useful life of 25 years. Therefore, the University will utilise it for a long time, earn more and contribute significantly towards Kenyan climate change and sustainability efforts.

Table 1: Total solar PV system earnings 2014-2017

\begin{tabular}{|l|c|c|c|c|}
\hline & $\mathbf{2 0 1 4}$ & $\mathbf{2 0 1 5}$ & $\mathbf{2 0 1 6}$ & $\mathbf{2 0 1 7}$ \\
\hline $\begin{array}{l}\text { Energy savings to the University } \\
\text { (70\% of the solar PV production) } \\
\text { at KES 19/kWhr (US\$ 0.19/kWhr) }\end{array}$ & $5,534,498.38$ & $10,463,266.25$ & $9,849,734.06$ & $5,143,639.71$ \\
\hline $\begin{array}{l}\text { Earnings from energy exported } \\
\text { to the grid (30\% of the solar PV } \\
\text { production) at KES 12/kWhr } \\
\text { (US\$ 0.12/kWhr) }\end{array}$ & $2,832,162.29$ & $2,832,162.29$ & $2,666,093.43$ & $1,392,263.38$ \\
\hline Total solar PV system earnings & $\mathbf{8 , 3 6 8 , 6 7 4 . 6 8}$ & $13,297,443.54$ & $12,517,843.49$ & $6,537,920.09$ \\
\hline
\end{tabular}

Source: SERC

\subsection{Solar PV project impacts}

The solar PV project has grown to be a lab promoting research and hands-on training for engineers and technicians. The live laboratory had by May 2017 trained over 1500 people. The capacity-building initiatives became necessary in order to create skills and knowledge required to install and maintain the grid-connected solar PV power plants.

Strathmore University has indeed contributed to Kenya's social development by adding electrical power-generation capacities. Strathmore University collaborated with GIZ and Kwale County government to install a $1.6 \mathrm{~kW}$ solar stand-alone system on Wasini Island in 2014. Today, the Wasini Island community is able to generate income through phone charging, internet café, photocopying and printing services, and selling of cold drinks.

\section{Conclusions}

The solar PV power system is challenged by the amount of solar insolation. Furthermore, production does not happen during the night but during the day only. Therefore, all the energy generated should be efficiently measured for internal consumption and dispatched efficiently to the grid.

As a result of Strathmore successfully installing the $600 \mathrm{~kW}$ solar PV power plant, it has earned a reputation across the region for leading in sustainability efforts. Through these efforts, it won the Private Sector award in the KAM Renewable Energy Project Awards in 2015 during the Kenya Clean Energy Conference. The success has attracted partners such as GIZ, DANIDA and DFID. Consequently, through sustainability partnerships, the University will be able to roll out solar power projects off the campus and propel Kenya to a sufficient energy production country. 
Grid-connected solar PV has brought all University stakeholders together to promote sustainability initiatives and address issues in climate change. SERC has conducted impactful live training sessions on installation and maintenance of solar PV power systems from the laboratory in the University. Additionally, there have been seminars to educate the students on the application of solar PV technologies. Hands-on training given to solar technicians has enabled the University to create agents of change who are acting as renewable energy ambassadors in the region. These initiatives not only motivate Kenya to improve its renewable energy production but also to become a low carbon emitter.

\section{References}

Adenle, A. et al. (2017). Managing climate change risks in Africa - A global perspective. Ecological Economics, 141(1):190-201. https://doi.org/10.1016/j.ecolecon.2017.06.004

Altan, H. (2010). Energy efficiency interventions in UK higher education institutions. Energy Policy, 38(12):7722-7731. https://doi.org/10.1016/j.enpol.2010.08.024

Avila, N., Carvallo, J., Shaw, B. \& Kammen, D. (2017). The energy challenge in sub-Saharan Africa: A guide for advocates and policy makers. OXFAM.

Bazilian, M. et al. (2012). Energy access scenarios to 2030 for the power sector in sub-Saharan Africa. Utilities Policy, 20(1):1-16. https://doi.org/10.1016/j.jup.2011.11.002

Bodansky, D. (2016). The Paris climate change agreement: A new hope? American Journal of International Law, 110(2):288-319. https://doi.org/10.5305/amerjintelaw.110.2.0288

Broome, J. (2008). The ethics of climate change. Scientific American, 298(6):96-102. https://doi.org/10.1038/ scientificamerican0608-96

Brown, D. (2013). Climate change ethics: Navigating the perfect moral storm. London: Routledge. https://doi. org/10.4324/9780203103234

Da Silva, I., Ronoh, G., Ouma, C. \& Jerono, C. (2015). Reducing carbon emissions in a third level educational institution in sub-Saharan Africa. In: Leal Filho, W. (ed.). Transformative approaches to sustainable development at universities: Working across disciplines. Cham: Springer. 513-524. https://doi. org/10.1007/978-3-319-08837-2_34

Da Silva, I.P. \& Ssekulima, E.B. (2015). Energy-efficient building envelope designs for institutional buildings in East Africa. Paper presented at the Domestic Use of Energy Conference held at the Cape Peninsula University of Technology, Cape Town, 30 March to 1 April.

Deichmann, U., Meisner, C., Murray, S. \& Wheeler, D. (2011). The economics of renewable energy expansion in rural sub-Saharan Africa. Energy Policy, 39(1):215-227. https://doi.org/10.1016/j.enpol.2010.09.034

Gardiner, S. (2004). Ethics and global climate change. Ethics, 114(3):555-600. https://doi.org/10.1086/382247

Government of Kenya. (2013). National Climate Change Action Plan 2013-2017. Nairobi: Government of Kenya.

Hogarth, J.R., Haywood, C. \& Whitley, S. (2015). Low-carbon development in sub-Saharan Africa: 20 crosssector transitions. London: Overseas Development Institute.

International Energy Agency. (2014). Africa energy outlook: A focus on energy prospects in sub-Saharan Africa. Paris: International Energy Agency. https://doi.org/10.1787/weo-2014-en

International Energy Agency. (2016). World energy outlook. Paris: International Energy Agency.

Maher, P., Smith, N. \& Williams, A. (2003). Assessment of pico hydro as an option for off-grid electrification in Kenya. Renewable Energy, 28(9):1357-1369. https://doi.org/10.1016/S0960-1481(02)00216-1

Nhamo, G. \& Ntombela, N. (2014). Higher education institutions and carbon management: Cases from the UK and South Africa. Problems and Perspectives in Management, 12(1):208-217. 
Oliver, J. et al. (2017). Energy pathways for achieving Kenya's nationally determined contribution on climate change. s.l.: s.n.

Oulu, M. (2014). Kenya's consideration of justice and ethics issues in formulating climate change policies. In: D.A. Brown \& P. Taylor (eds.). Ethics and climate change: A study of national commitments. Gland: IUCN. 87-94.

Shum, K. \& Watanabe, C. (2009). An innovation management approach for renewable energy deployment the case of solar photovoltaic (PV) technology. Energy Policy, 37(9):3535-3544. https://doi.org/10.1016/j. enpol.2009.04.007

Silva, D. (2013). Towards a sustainable Strathmore University: 600 Grid Connected Solar Energy System. https:// www.strathmore.edu/news/towards-a-sustainable-strathmore-university-600-kw-grid-connected-solarenergy-system/ [Accessed 5 September 2018].

Strathmore University. (2018). History of Strathmore University. https://www.strathmore.edu/aboutstrathmore/history/ [Accessed 4 September 2018].

Strathmore University Annual Report. (2015). Annual Report. https://www.strathmore.edu/wp-content/ uploads/2016/10/AnnualReport2015.pdf [Accessed 4 September 2018].

Uhl, C. \& Anderson, A. (2001). Green destiny: Universities leading the way to a sustainable future. BioScience, 51(1):36-42.

World Bank. (2016). CO2 emissions (metric tons per capita) in sub-Saharan Africa. http://data.worldbank.org/ indicator/EN.ATM.CO2E.PC?locations=ZG [Accessed 29 June 2017]. 